\author{
RESEARCH ARTICLE \\ 10.1029/2019JF005035 \\ Key Points: \\ - Large, deep-seated, slow-moving \\ landslides show size-dependent \\ sensitivity to large changes in annual \\ rainfall \\ - The extreme wet season of 2017 \\ triggered a widespread but \\ short-lived increase in landslide \\ activity and velocity \\ - Ongoing climate shifts in California \\ will likely cause an overall increase \\ in landslide activity over the next \\ century
}

Supporting Information:

- Supporting Information S1

- Table S1

- Table S2

Correspondence to:

A. L. Handwerger,

alexander.handwerger@jpl.nasa.gov

Citation:

Handwerger, A. L., Fielding, E. J., Huang, M.-H., Bennett, G. L.,

Liang, C., \& Schulz, W. H. (2019).

Widespread initiation, reactivation, and acceleration of landslides in the northern California Coast Ranges due to extreme rainfall. Journal

Geophysical Research: Earth

Surface, 124. https://doi.org/10.1029/ 2019JF005035

Received 13 FEB 2019

Accepted 11 JUN 2019

Accepted article online 19 JUN 2019

(C)2019. American Geophysical Union. All Rights Reserved.

\section{Widespread Initiation, Reactivation, and Acceleration of Landslides in the Northern California Coast Ranges due to Extreme Rainfall}

\author{
Alexander L. Handwerger ${ }^{1}$, Eric J. Fielding ${ }^{(}$, Mong-Han Huang ${ }^{2}($, \\ Georgina L. Bennett ${ }^{3}$, Cunren Liang ${ }^{4}$, and William H. Schulz ${ }^{5}(\mathbb{C}$ \\ ${ }^{1}$ Jet Propulsion Laboratory, California Institute of Technology, Pasadena, CA, USA, ${ }^{2}$ Department of Geology, University \\ of Maryland, College Park, MD, USA, ${ }^{3}$ School of Environmental Sciences, University of East Anglia, Norwich, UK, \\ ${ }^{4}$ California Institute of Technology, Seismological Laboratory, Pasadena, CA, USA, ${ }^{5}$ U.S. Geological Survey, Denver, CO, \\ USA
}

Abstract Episodically to continuously active slow-moving landslides are driven by precipitation. Climate change, which is altering both the frequency and magnitude of precipitation worldwide, is therefore predicted to have a major impact on landslides. Here we examine the behavior of hundreds of slow-moving landslides in northern California in response to large changes in annual precipitation that occurred between 2016 and 2018. We quantify the landslide displacement using repeat-pass radar interferometry and pixel offset tracking techniques on a novel data set from the airborne NASA/JPL Uninhabited Aerial Vehicle Synthetic Aperture Radar. We found that 312 landslides were moving due to extreme rainfall during 2017, compared to 119 during 2016, which was the final year of a historic multiyear drought. However, with a return to below to average rainfall in 2018, only 146 landslides remained in motion. The increased number of landslides during 2017 was primarily accommodated by landslides that were smaller than the landslides that remained active between 2016 and 2018. Furthermore, by examining a subset of 51 landslides, we found that 49 had increased velocities during 2017 when compared to 2016. Our results show that slow-moving landslides are sensitive to large changes in annual precipitation, particularly the smaller and thinner landslides that likely experience larger basal pore-water pressure changes. Based on climate model predictions for the next century in California, which include increases in average annual precipitation and increases in the frequency of dry-to-wet extremes, we hypothesize that there will be an overall increase in landslide activity.

\section{Introduction}

In mountainous regions around the world, landslides dominate erosion and landscape evolution (Booth et al., 2013; Kelsey, 1978; Korup et al., 2007; Larsen et al., 2010; Mackey \& Roering, 2011; Simoni et al., 2013) and pose a major natural hazard that causes billions of dollars in damages and claims thousands of lives annually (Froude \& Petley, 2018; Kirschbaum et al., 2015). Numerous factors, such as rainfall, snowmelt, earthquakes, river incision, and human activities can alter the stress balance along a hillslope and trigger landslides. However, once they occur, they can display a wide range of behaviors. The most hazardous landslides fail catastrophically and can move kilometers downslope at rates up to tens of meters per second (e.g., Bell, 2018; Iverson et al., 2015). Less hazardous, but still destructive, are landslides that move downslope at rates as low as millimeters to meters per year (herein referred to as "slow-moving landslides") and can remain active for decades or longer (e.g., Bennett, Roering, et al., 2016; Bovis \& Jones, 1992; Keefer \& Johnson, 1983; Nereson \& Finnegan, 2018). The persistent and long-term motion of slow-moving landslides makes them particularly well suited for investigations that aim to better understand landslide processes.

Slow-moving landslides occur worldwide in regions that have mechanically weak, clay-rich materials (i.e., soil and rock) and high seasonal precipitation (e.g., Cerovski-Darriau \& Roering, 2016; Malet et al., 2002; Miao et al., 2014; Rutter \& Green, 2011; Simoni et al., 2013). These landslides can display kinematic changes over timescales ranging from $10^{-2}$ to $10^{2}$ days in response to stress perturbations that act to alter the driving stress or resisting strength. Stress perturbations caused by nearby earthquakes (e.g., Lacroix et al., 2015), variations in atmospheric pressure (e.g., Schulz, Kean, \& Wang, 2009; Van Genuchten \& De Rijke, 1989), and 
undrained loading (e.g., Booth et al., 2018; Hutchinson \& Bhandari, 1971) have all been linked to observable changes in landslide behavior. Most commonly, however, stress changes from infiltrating precipitation and snowmelt drive changes in landslide activity (e.g., Coe et al., 2003; Iverson \& Major, 1987; Malet et al., 2002; Rutter \& Green, 2011; Terzaghi, 1950).

Climate change, which is altering both the frequency and magnitude of precipitation worldwide, is thus predicted to have a major impact on landslides (Crozier, 2010; Gariano \& Guzzetti, 2016; Jakob \& Lambert, 2009). Regional increases in the intensity, duration, and amount of precipitation will likely trigger or increase the activity of landslides by generating elevated pore-water pressures that reduce the effective normal stress (normal stress minus pore-water pressure) and consequently decrease the frictional strength of hillslopes (Terzaghi, 1950). For example, Chiang and Chang (2011) used landslide and climate models to predict up to a $12 \%$ increase in unstable hillslopes in Taiwan over the next century due to increased rainfall. In contrast, regional decreases in rainfall or increases in drought conditions will likely reduce landslide activity. Coe (2012) combined over a decade of continuous landslide monitoring data with climate models to predict a decrease in the activity of the Slumgullion landslide, Colorado, over the next century due to decreased rainfall and increased temperature. Additionally, changes in rainfall patterns may have different effects on shallow and deep-seated landslides (Crozier, 2010; Gariano \& Guzzetti, 2016). Shallow landslides are more sensitive to changes in the intensity and duration of individual storms (e.g., Chiang \& Chang, 2011; Iverson, 2000), while deep-seated landslides are more sensitive to changes in seasonal and annual precipitation (e.g., Iverson \& Major, 1987; Malet et al., 2002; Rutter \& Green, 2011). However, uncertainties in landslide and climate models make it difficult to assess how landslides will respond to climate change.

Recent and ongoing climate shifts in California have already had an impact on the behavior and activity of landslides (Bennett, Roering, et al., 2016; East et al., 2018; Handwerger et al., 2019; Nereson \& Finnegan, 2018). Over the past decade, California has experienced both a historic drought (2012-2016) and the second wettest year on record (2017; Griffin \& Anchukaitis, 2014; Robeson, 2015; Swain et al., 2016, 2018). Bennett, Roering, et al. (2016) found that the mean velocity of slow-moving landslides in the northern California Coast Ranges reached a 70-year minimum during the recent historic drought. Slow-moving landslides in the central California Coast Ranges also displayed minimum velocities during the drought (Nereson \& Finnegan, 2018) but displayed high velocities during the extreme wet year of 2017 (Handwerger et al., 2019; Warrick et al., 2019). Rapid shifts from dry-to-wet extremes in California, similar to the changes in precipitation that occurred between 2012 and 2018, are predicted to increase by $25 \%$ to $100 \%$ during the 21 st century (Swain et al., 2018). In addition to these changes in precipitation extremes, annual mean precipitation could increase by $12 \%$ across the state (Allen \& Luptowitz, 2017). If these climate model predictions hold true, there could be an increase in both landslide activity and landslide hazards.

To better understand how landslides respond to rapid climate shifts, such as the recent transition from historic drought to the second wettest year on record, we map and quantify the kinematic response of hundreds of slow-moving landslides in the Eel River catchment, northern California Coast Ranges, between 2016 and 2018. Tracking the time-dependent behavior of large inventories of landslides is necessary to determine their hazard potential and the role they play in landscape evolution. State-of-the-art remote sensing techniques, such as satellite and airborne synthetic aperture radar interferometry (InSAR), provide millimeterto centimeter-scale measurements of ground surface change that can be used to quantify landslide motion across entire mountain ranges (e.g., Bayer et al., 2018; Colesanti \& Wasowski, 2006; Scheingross et al., 2013). These monitoring tools, combined with field and laboratory measurements, help to improve our understanding of the mechanisms that control landslides and allow us to better understand how landslides respond to environmental changes, such as the warming global climate.

Here we identify and monitor active landslides using InSAR and pixel offset tracking techniques with a novel data set from the NASA/JPL Uninhabited Aerial Vehicle Synthetic Aperture Radar (UAVSAR) that we designed specifically to monitor the Eel River landslides. This is the first study to use UAVSAR data to track the time-dependent motion of numerous slow-moving landslides in response to large changes in rainfall. We examine relationships between landslide activity, displacement, velocity, geometry, and precipitation to document how large hydrologic changes impact landslide activity and kinematics. We also discuss the implications of our findings for understanding landslide mechanisms and how ongoing and future climate change may affect landslide behaviors and landscape evolution. 


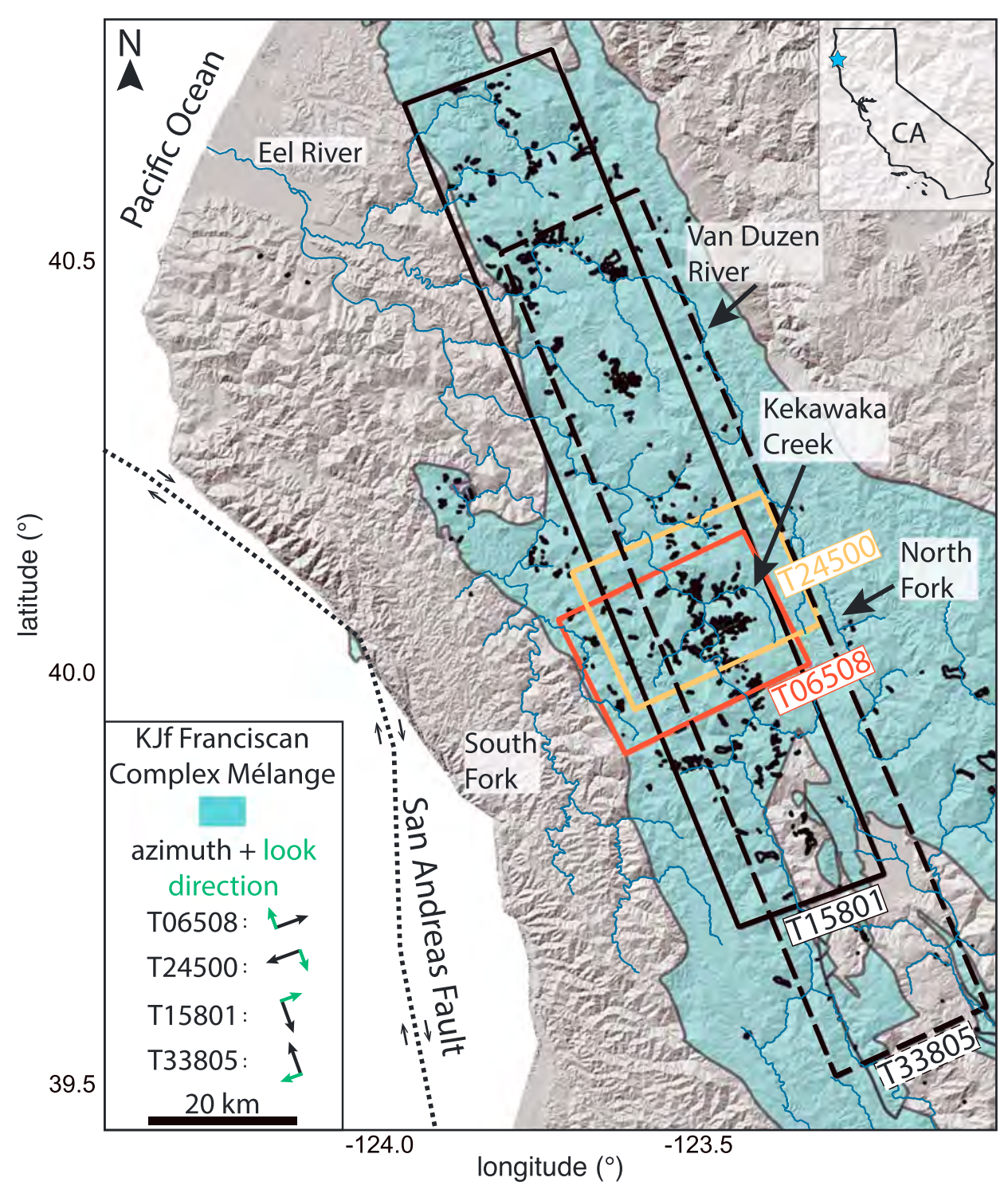

Figure 1. Eel River catchment, northern California. Uninhabited Aerial Vehicle Synthetic Aperture Radar flight paths (black and colored rectangles) and Franciscan Complex mélange (Jennings et al., 1977) draped over a hillshade of the topography. The azimuth (along track) and look direction of the Uninhabited Aerial Vehicle Synthetic Aperture Radar instruments are shown with black and green arrows in the legend. Black polygons show mapped slow-moving landslides from this study and from previously published inventories (Bennett, Miller, et al., 2016; Handwerger et al., 2015; Mackey \& Roering, 2011). Thin blue lines show major rivers and tributaries. Dotted line shows San Andreas Fault, and arrows show relative fault motion. Inset shows field site location within California. Digital elevation model from TanDEM-X.

\section{Study Area: Northern California Coast Ranges}

Our study focuses on a $\sim 4,700-\mathrm{km}^{2}$ area that contains hundreds of episodically to continuously active slow-moving landslides located within the Eel River catchment, northern California Coast Ranges (Figure 1). Due to high landslide activity, the northern California Coast Ranges have been a focus site for landslide investigations for over four decades (Bennett, Miller, et al., 2016; Bennett, Roering, et al., 2016; Booth \& Roering, 2011; Booth et al., 2013, Handwerger et al., 2013, 2015; Iverson \& Major, 1987; Kelsey, 1978; Mackey et al., 2009; Mackey \& Roering, 2011; Mackey et al., 2011; Roering et al., 2009, 2015; Schulz, Smith, Wang, Jiang, \& Roering, 2018; Zhao et al., 2012). Nearly all of the slow-moving landslides are underlain by the Jurassic-Cretaceous Franciscan Complex mélange (Figure 1), which comprises tectonically sheared sandstone, siltstone, shale, meta-sandstone, greenstone, chert, blueschist, and serpentinite 


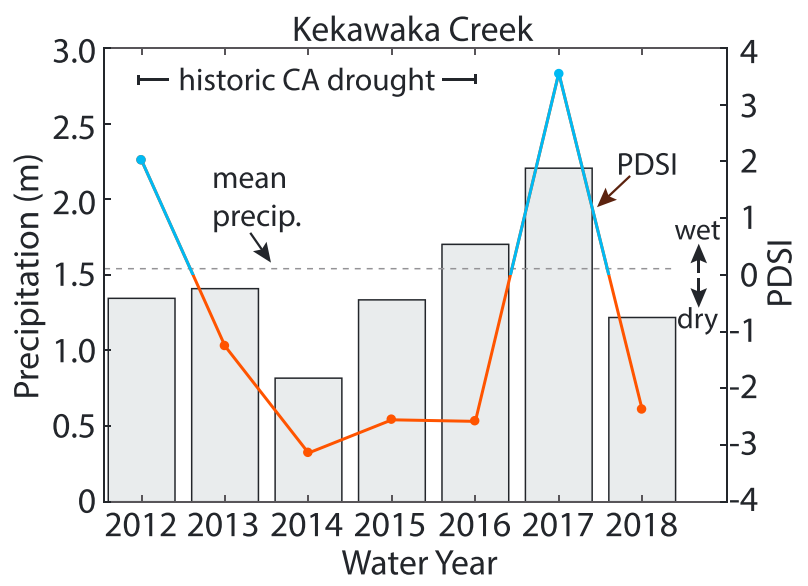

Figure 2. Water year precipitation for Kekawaka Creek, CA. Gray bars show cumulative water year (1 October to 30 September) precipitation for $16 \mathrm{~km}^{2} \mathrm{~km}$ region. Dashed gray line corresponds to average rainfall between 1895 and 2018. Line with dots shows the Palmer Drought Severity Index (PDSI) with positive values corresponding to wet conditions (blue) and negative values corresponding to dry conditions (orange). Precipitation data from Parameter-elevation Regressions on Independent Slopes Model and PDSI data from the WestWide Drought Tracker.
(Jayko et al., 1989; Jennings et al., 1977; McLaughlin et al., 1982; McLaughlin et al., 2000). The vegetation in the slow-moving landslide-prone areas of the Eel River catchment consists of open oak grassland; and the region is primarily used for cattle grazing and agriculture (Kelsey, 1978; Mackey \& Roering, 2011).

The northern California Coast Ranges have a Mediterranean climate with seasonal precipitation that occurs primarily between October and May, $30-50 \%$ of which is delivered by landfalling atmospheric rivers (Dettinger et al., 2011). Our field area is centered on Kekawaka Creek (Figure 1), which has a long-term average annual precipitation of $\sim 1.55 \mathrm{~m}$ (Figure 2), calculated between the 1895 and 2018 water years (WYs) using data from the Parameter-elevation Regressions on Independent Slopes Model Climate Group at Oregon State University. Note the WY is defined as the time period between 1 October and 30 September, such that WY2017 = 1 October 2016 to 30 September 2017. Average annual precipitation varies across the northern California Coast Ranges with the largest cumulative precipitation occurring in the Northwest and decreasing toward the Southeast (Figures 3 and S1 in the supporting information).

Recent climate shifts in California have already had severe consequences on water supply, agriculture, infrastructure, wildfires, ground subsidence, sediment flux, and landslides (Bekaert et al., 2019; Bennett, Roering, et al., 2016; Chaussard et al., 2017; Diffenbaugh et al., 2015; East et al., 2018; Handwerger et al., 2019; Murray \& Lohman, 2018; Swain et al., 2018). Between the 2012 and 2018 WYs, California experienced one of its most extreme droughts and the second wettest year in recorded history (Diffenbaugh et al., 2015; Griffin \& Anchukaitis, 2014; Swain et al., 2018). In the Kekawaka Creek area, minimum rainfall was $0.82 \mathrm{~m}$ during WY2014, and maximum rainfall was $2.21 \mathrm{~m}$ during WY2017 (Figure 2). The extreme rainfall during WY2017 resulted from an unusually high number of atmospheric river storms, including the strongest atmospheric river event in the past 70 years (Gershunov et al., 2017; Guirguis et al., 2018; Swain et al., 2018). These large changes in rainfall subsequently caused transitions between dry and wet soil moisture conditions, as quantified by the Palmer Drought Severity Index (PDSI; Figure 2). The PDSI (data provided by the WestWide Drought Tracker) is an estimate of relative dryness (negative and positive values correspond to dry and wet conditions, respectively) and serves as a good proxy for the conditions that drive landslide motion because it is based on temperature and precipitation data and accounts for antecedent conditions (Bennett, Roering, et al., 2016; Nereson \& Finnegan, 2018). The PDSI
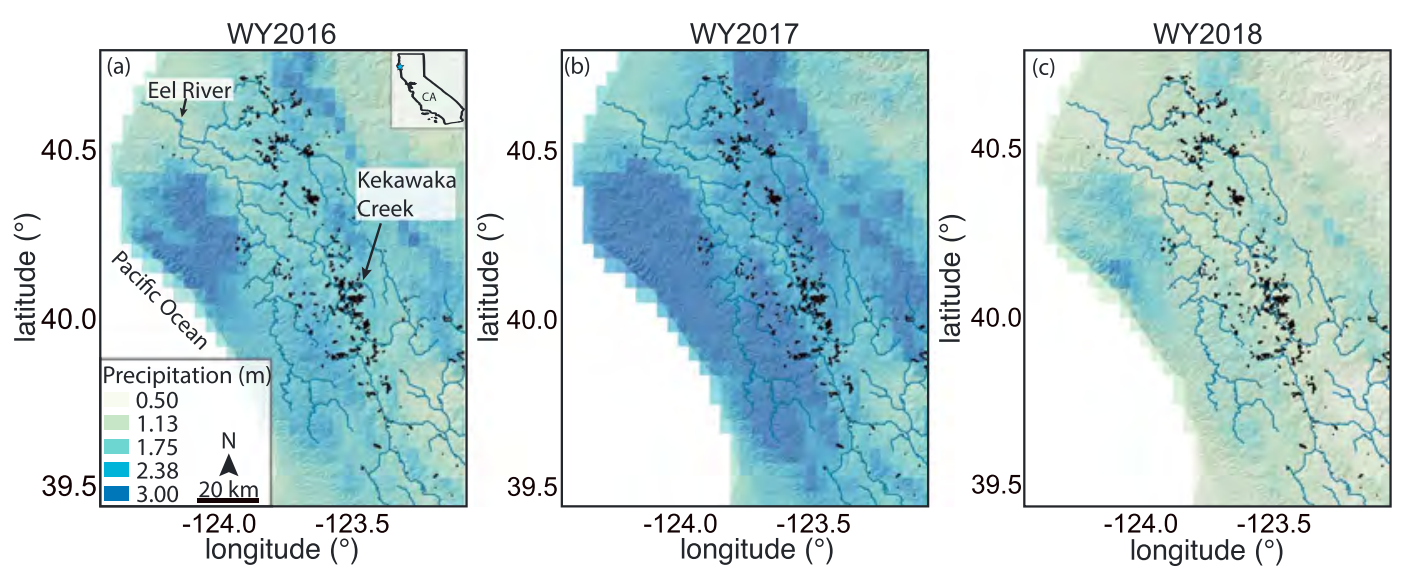

Figure 3. Precipitation maps for northern California Coast Ranges. (a-c) Cumulative precipitation for the 2016-2018 water years (WYs) draped over a hillshade of the topography. Black polygons show mapped slow-moving landslides from this study and from previously published inventories (Bennett, Miller, et al., 2016; Handwerger et al., 2015; Mackey \& Roering, 2011). Thin blue lines show major rivers and tributaries. Precipitation data from Parameter-elevation Regressions on Independent Slopes Model and digital elevation model from TanDEM-X. 
shows dry conditions between WY2013 and WY2016 and in WY2018 and wet conditions in WY2012 and WY2017 (Figure 2). Although WY2012 was the first year of the historic California drought, the Kekawaka Creek area received sufficient rainfall in preceding years such that wet soil conditions were maintained and the multiyear period of dry soil conditions began in WY2013. Our study focuses on the period between WY2016 and WY2018, during which time the PDSI shows a transition from dry to wet to dry conditions.

Slow-moving landslides in the Eel River catchment are often large ( $>500 \mathrm{~m}$ long), deep-seated ( $>3 \mathrm{~m}$ thick) masses that move downslope at rates up to several meters per year (Bennett, Miller, et al., 2016; Bennett, Roering, et al., 2016; Handwerger et al., 2013, 2015; Mackey \& Roering, 2011). Due to their flow-like appearance, these landslides are often referred to as earthflows; however, most of their displacement occurs by sliding along narrow basal and lateral shear zones (Keefer \& Johnson, 1983; Nereson \& Finnegan, 2018; Schulz, Smith, Wang, Jiang, \& Roering, 2018). Similar types of slow-moving landslides occur in mountainous areas around the world (Cerovski-Darriau \& Roering, 2016; Malet et al., 2002; Miao et al., 2014; Rutter \& Green, 2011; Simoni et al., 2013). The slow-moving landslides occur in a mechanically weak (friction angle $\sim 15^{\circ}$ ), clayey granular soil (chlorite, illite/mica, and smectite) with low hydraulic diffusivity ( 10 $0^{-6} \mathrm{~m}^{2} / \mathrm{s}$; Iverson \& Major, 1987; Keefer \& Johnson, 1983; Nereson et al., 2018; Schulz, Smith, Wang, Jiang, \& Roering, 2018; Schulz, Smith, Wang, Jiang, Deuell, et al., 2018).

Historical optical imagery has been used to track the activity of many of the Eel River slow-moving landslides for over 70 years (Bennett, Roering, et al., 2016; Mackey \& Roering, 2011). These landslides display unsteady motion with velocities that are highly variable both within a single landslide and between neighboring landslides (Handwerger et al., 2013, 2015; Mackey et al., 2009). Over seasonal timescales, the Eel River landslides exhibit velocity changes that generally correspond to precipitation-induced changes in pore-water pressure (Iverson \& Major, 1987; Schulz, Smith, Wang, Jiang, \& Roering, 2018; Schulz, Smith, Wang, Jiang, Deuell, et al., 2018). Typically, each landslide accelerates during the wet season and decelerates throughout the dry season. However, the timing of speed minima and maxima and sliding behavior can vary from year to year (Handwerger et al., 2013; Schulz, Smith, Wang, Jiang, \& Roering, 2018). Furthermore, the seasonal velocity changes displayed by these slow-moving landslides are superimposed onto yearly-and decadal—scale velocity variations (Bennett, Roering, et al., 2016; Mackey et al., 2009). Mackey et al. (2009) found that the Kekawaka landslide (located in our field area; see Figure 4) reached peak velocities between 1964 and 1981 and then decelerated until 2006. They suggested that the peak velocities were a result of a particularly wet time period in California. Bennett, Roering, et al. (2016) analyzed the behavior of 98 Eel River landslides and showed that the mean velocity of the landslides decreased 85\% between 1944 and 2015, with minimum velocities coinciding with the historic drought between 2012 and 2015. Furthermore, they showed that these velocity changes are correlated with the PDSI such that periods of increased dryness (i.e., drought) correspond to low landslide velocities. Nereson and Finnegan (2018) also found that the PDSI serves as a good proxy for the conditions that drive increased or decreased landslide motion for the transport zone of the Oakridge landslide in central California. In order to better understand how landslides will respond to future and ongoing climate shifts, we explore how the recent transition from dry to wet conditions impacted the landslide activity in northern California.

\section{Methods}

\subsection{InSAR and Pixel Offset Tracking}

Satellite and airborne InSAR provide millimeter- to centimeter-scale measurements of surface deformation and have been used to quantify the ground surface deformation associated with landslides (e.g., Bayer et al., 2018; Hu et al., 2016; Schlögel et al., 2015), faults (e.g., Fielding et al., 2005; Fialko et al., 2001; Huang et al., 2017), glaciers (e.g., Gourmelen et al., 2011; Milillo et al., 2019), and ground subsidence (e.g., Bekaert et al., 2019; Chaussard et al., 2017; Murray \& Lohman, 2018). Previous studies have used satellite-based InSAR to identify and monitor slow-moving landslides in the California Coast Ranges (Cohen-Waeber et al., 2018; Handwerger et al., 2013, 2015, 2019; Hilley et al., 2004; Roering et al., 2009, 2015; Zhao et al., 2012). InSAR techniques work particularly well for monitoring slow-moving landslides in the California Coast Ranges because they have sparse vegetation and move downslope at relatively low rates.

We use a novel data set from the NASA/JPL UAVSAR airborne system that we designed specifically to monitor the Eel River landslides (Figures 1 and 4). Previous work by Delbridge et al. (2016) used UAVSAR data to 

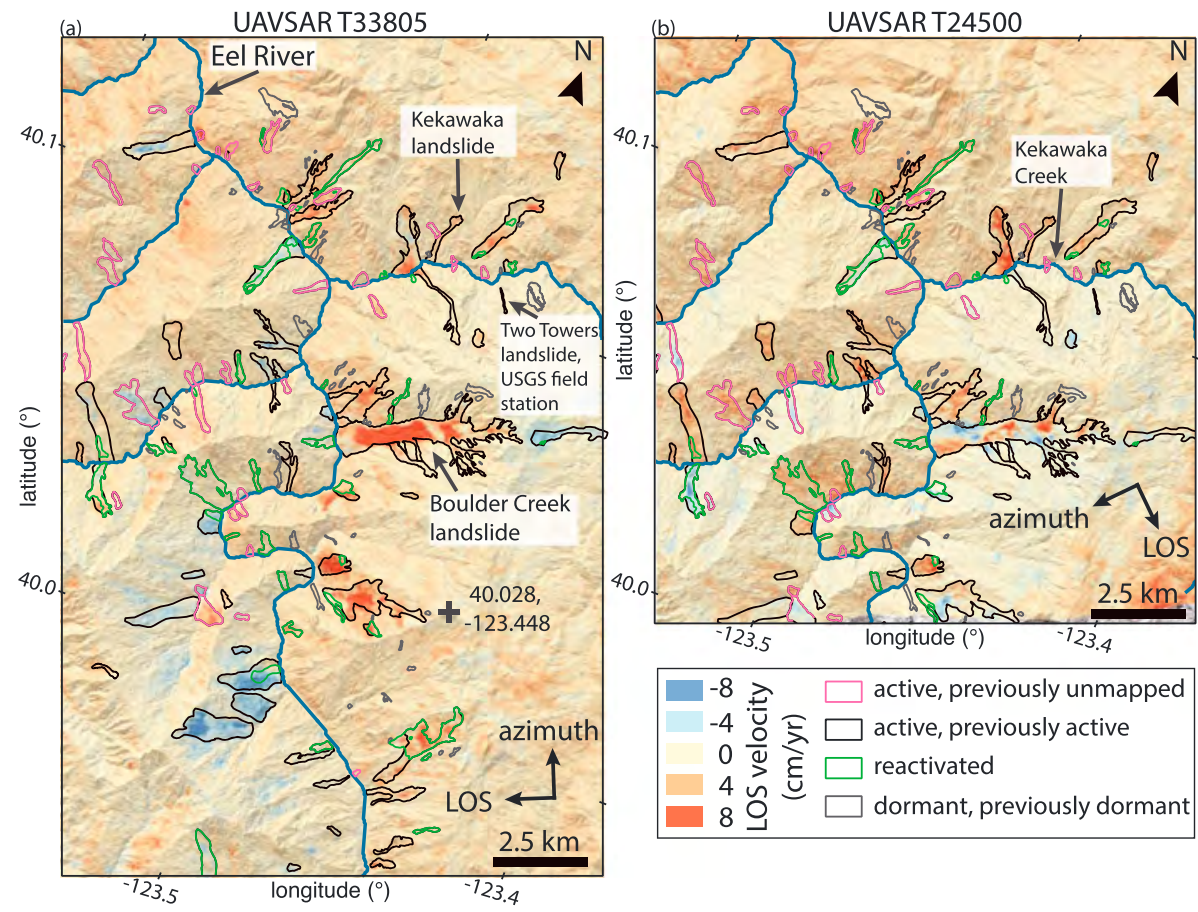

Figure 4. Average velocity maps for two Uninhabited Aerial Vehicle Synthetic Aperture Radar (UAVSAR) flight paths. Average line-of-sight (LOS) velocity between April 2016 and February 2018 draped over a hillshade of the topography. Red and blue colors correspond to active landslide deformation. Differences in velocity between UAVSAR track 33805 (a) and track 24500 (b) are related to the changes in the look geometry of the UAVSAR. The azimuth (along track) and look direction of the UAVSAR instruments are shown with black arrows. Changes in the activity of the landslides are based on a previously published inventory from Bennett, Miller, et al. (2016). Thin blue lines show major rivers and tributaries. Digital elevation models from OpenTopography and TanDEM-X.

measure the 3-D kinematics of the Slumgullion landslide, Colorado; and previous work by Scheingross et al. (2013) used UAVSAR data to map 150 landslides and explore their relation to the creeping section of the San Andreas Fault in central California. Our study is the first to use UAVSAR data to track the time-dependent behavior of hundreds of slow-moving landslides in response to large changes in rainfall. The UAVSAR system is flown aboard a NASA Gulfstream III and acquires data with a L-band (24-cm radar wavelength) radar that has a pixel size of $0.6 \mathrm{~m}$ in azimuth and $1.67 \mathrm{~m}$ in range. For each data acquisition (dates listed in Table S1), data were acquired along four different flight paths, and thus, each flight provides four line-of-site measurements when processed to interferograms. SAR data were acquired eight times between April 2016 and February 2018 (Table S1). We process all possible combinations of interferograms, which results in 112 interferograms (28 along each flight path; Figure S2 and Table S1). The minimum time between a single interferogram pair is 47 days, and the maximum time is 673 days. We process the data from UAVSAR Single Look Complex stacks using the InSAR Scientific Computing Environment software package developed at JPL/Caltech/Stanford (Rosen et al., 2012) with eight looks in azimuth and three looks in range, resulting in a $4.8-\mathrm{m}$ azimuth by $5-\mathrm{m}$ range pixel size. To remove topographic contributions to the phase and to geocode the interferograms, we use a 12-m pixel spacing digital elevation model (DEM) from the German Aerospace Center (DLR) TanDEM-X and reduce phase noise by applying a standard power spectrum filter with a filtering parameter value of 0.7 (Goldstein \& Werner, 1998).

The persistent downslope motion and large deformation gradients of slow-moving landslides can introduce phase unwrapping errors when using conventional InSAR techniques to process long-time-span interferograms. These errors occur when the displacement between adjacent pixels exceeds half the radar wavelength. An example of InSAR unwrapping errors at the Boulder Creek landslide is shown in Figure S3. To overcome these types of unwrapping errors, previous studies implemented a deformation model into the InSAR processing that helped remove large phase gradients (Handwerger et al., 2013, 2015, 2019). While this technique can improve the quality of interferograms, it requires a deformation model for each landslide and is therefore best suited for studies that focus on a small numbers of landslides. Therefore, we also use pixel 
offset tracking with SAR data to overcome issues associated with large displacements. Our pixel offset tracking uses incoherent cross correlation of the SAR amplitude images to calculate offsets (i.e., displacements) of nearly identical features. Pixel offset tracking circumvents issues related to high deformation rates because it does not require phase unwrapping. In addition, it also provides two-dimensional measurements (i.e., look direction and along-track direction). This technique has been used with both SAR data and optical imagery to successfully measure large displacements associated with landslides, faults, and glaciers (e.g., Bao et al., 2019; Bennett, Roering, et al., 2016; Dehecq et al., 2015; Fialko et al., 2001; Huang et al., 2017; Leprince et al., 2008; Pathier et al., 2006; Stumpf et al., 2017). However, pixel offset tracking is less accurate (i.e., sensitive to $1 / 20$ of the pixel size) than conventional InSAR and is therefore best suited for landslides that move at least decimeters to meters per year and for data sets with high spatial resolution such as UAVSAR. We process pixel offsets from the full-resolution SAR Single Look Complex images using the standard InSAR Scientific Computing Environment amplitude matching program. We explored a range of correlation window sizes from 16 to 256 and found that a matching window of 64 range $\times 128$ azimuth provided the best landslide deformation signal. We process all possible combinations of SAR data, resulting in 112 pixel offset maps (28 on each flight path; Figure S2 and Table S1).

\subsection{Time Series and Three-Dimensional Surface Displacement Inversions}

We construct cumulative displacement time series inversions from the UAVSAR pixel offset tracking measurements using the Generic InSAR Analysis Toolbox (Agram et al., 2013) with the Small Baseline Subset method (Berardino et al., 2002; Schmidt \& Bürgmann, 2003). We then use data from overlapping flight paths to invert for 3-D surface displacement time series. The 3-D inversions require three or more independent measurements of ground displacement. Each flight path provides two independent measurements using pixel offset tracking (i.e., range and azimuth). We combine four independent measurements for areas where two flight paths overlap and six independent measurements for areas where three flight paths overlap.

Each measurement from the UAVSAR is composed of the true displacement vector projected onto the look direction or along-track (i.e., azimuth) direction of the UAVSAR. Using the overlapping measurements and information about the geometry of the UAVSAR allows us to solve for the true 3-D motion using a least squares inversion (details described in Delbridge et al., 2016). We perform the least squares inversion using the MATLAB software package. We also quantified errors in the pixel offset displacement measurements by calculating the mean and standard deviation values across a $\sim 10-\mathrm{km}^{2}$ region with no active landslides. The mean displacement error over the full study period was $0.09 \pm 0.05 \mathrm{~m}$ ( \pm 1 standard deviation). To help reduce errors in the displacement measurements, we apply displacement thresholds to the time series inversion. We remove all pixels with cumulative horizontal displacements $<0.2$ and $>20 \mathrm{~m}$ over the full study period. This essentially removes all stable areas and areas that have displacements that significantly exceed those displayed by the Eel River landslides (cm/year to m/year) (Bennett, Roering, et al., 2016; Handwerger et al., 2015; Mackey \& Roering, 2011).

\subsection{Landslide Reconnaissance and Metrics}

We construct a new inventory of landslides active between April 2016 and February 2018. We initially identify active landslides using InSAR velocity maps. To be considered active, the landslides need to display clear ground surface deformation during the study period. We then use the high-resolution DEMs, Google Earth images, and previously published inventories (Bennett, Miller, et al., 2016; Handwerger et al., 2015; Mackey \& Roering, 2011) to confirm that the deformation signals correspond to landslides. Figure 4 shows an example of InSAR velocity maps and landslide inventories for two different UAVSAR flight tracks. Areas with relatively high positive or negative line-of-sight velocities generally correspond to active landslides. The positive and negative values indicate motion toward or away from the UAVSAR radar, respectively.

To explore how changes in precipitation and relative dryness (i.e., PDSI) affected the landslide activity, we delineate our landslide inventory into three WY periods, which encompassed the following: (1) WY2016 (7 April 2016 to 4 October 2016), (2) WY2017 (4 October 2016 to 30 October 2017), and (3) WY2018 (30 October 2017 to 9 February 2018). These time periods are set by the UAVSAR data acquisitions. Although only the second time period spans a full WY, and all three periods lie outside the defined start and end of the WY (i.e., 1 October to 30 September), our analysis generally covers the period of increased seasonal activity in the Eel River landslides (November to June; Handwerger et al., 2013, 2015). In addition, the seasonal patterns of precipitation were relatively consistent, with the onset of seasonal rainfall beginning in October and ending in June (Figure S5). Therefore, we assume the landslide inventories are approximately representative of each 
WY. However, we note that our inventories likely underestimate the number of active landslides during WY2016 and WY2018.

We quantify the spatial attributes (i.e., area, length, width, and slope angle) of each landslide using the 12-m TanDEM-X DEM. We also estimate the landslide thickness, which is the most important length scale in controlling their response to seasonal precipitation (e.g., Berti \& Simoni, 2012; Iverson, 2000). We estimate thickness from field-based observations and area-thickness geometric scaling relations defined as $Z=\alpha A^{\gamma}$, where $Z$ is the landslide thickness, $\gamma$ is the power law exponent, $\alpha$ is a fit parameter, and $A$ is the landslide area (Guzzetti et al., 2009; Larsen et al., 2010; Handwerger et al., 2013; Simoni et al., 2013). Field-based estimates of thickness for landslides in our study site were made from lidar and field observations of 69 landslides where transects into the landslide body were exposed by incised channels and gullies (Mackey \& Roering, 2011). These thickness estimates are considered the minimum landslide thickness because no basal shear zones were observed. Using these data, Handwerger et al. (2013) found $\alpha=0.46$ and $\gamma=0.29$. These scaling relations are comparable to those derived from borehole data $(\alpha=0.44$ and $\gamma=0.31)$ from similar types of slow-moving landslides in Italy (Simoni et al., 2013). We emphasize that without actual measurements of landslide thickness, we treat these as first-order estimates to characterize landslides as relatively thinner or thicker.

\section{Results}

\subsection{Landslide Activity}

In total, we identified 312 active landslides during our $\sim 2$-year study period that range in planform area from $7.4 \times 10^{3}$ to $3.1 \times 10^{6} \mathrm{~m}^{2}$ and mean slope angle from $11^{\circ}$ to $39^{\circ}$ (Table S2). Comparison with the inventory compiled by Bennett, Miller, et al. (2016) reveals 102 landslides that were previously unmapped; 123 active landslides mapped by both studies; 58 landslides that enlarged in planform area; 71 landslides that were mapped as active by Bennett, Miller, et al. (2016) but did not display clear deformation signals in our dataset; 87 reactivated landslides (i.e., mapped as dormant by Bennett, Miller, et al., 2016); and 167 landslides that were mapped as dormant by both studies (i.e., previously mapped landslides that showed no active deformation). The previously unmapped landslides were either recently triggered or were possibly missed by Bennett, Miller, et al. (2016), who manually mapped landslides using satellite and aerial optical images. The differences in our landslide inventories can result from real changes in landslide activity, bias from the different mapping techniques (InSAR vs. optical images), and from human error (i.e., manual landslide mapping). Lastly, we further classified 53 of the landslides as "possible landslides" because they displayed a strong InSAR signal similar to the other active landslides but were covered with dense vegetation, making it difficult to observe surface deformation features using our additional criteria (e.g., Google Earth images).

The landslide activity also changed in time due to the large changes in precipitation. We mapped 119 active landslides during WY2016, 312 landslides during WY2017, and 146 landslides during WY2018 (Figure 5 and Table S2). There were also changes in the individual landslides moving each year. We found 93 landslides that were active during all three WYs, 5 landslides that were only active during WY2016, 185 landslides that were only active during WY2017, and 17 landslides that were only active during WY2018. Figure 5 shows the cumulative frequency-magnitude (i.e., landslide area) relationship and the kernel density estimate (i.e., probably density) for our landslide inventories. We found that there was a similar distribution of landslides during WY2016 and WY2018 and that the increased landslide frequency during WY2017 was accommodated by smaller landslides with areas $<1 \times 10^{5} \mathrm{~m}^{2}$ and estimated thicknesses $<15 \mathrm{~m}$ (Figure 5). Using a two-sample Kolmogorov-Smirnov test for landslide area (significance level 0.01), we can reject the null hypothesis that the landslides only active during WY2017 are from the same distribution as landslides moving during all three WY. Finally, there are no clear differences in the distributions of the landslide spatial attributes (i.e., slope, length, and width), other than area (i.e., thickness), that can be used to differentiate the inventories during the three WYs (Table S2). For example, using the two-sample Kolmogorov-Smirnov test for mean slope angle, we cannot reject the null hypothesis that the landslides only active during WY2017 are from the same distribution as landslides moving during all three WY.

\subsection{Landslide Kinematics}

Each landslide generally displayed a nonuniform spatial velocity pattern, that is, some parts are moving faster than others (Figure 4). These spatial velocity patterns remained fixed during our study period and are similar to those patterns observed between 1944 and 2015 (Bennett, Roering, et al., 2016; Handwerger 

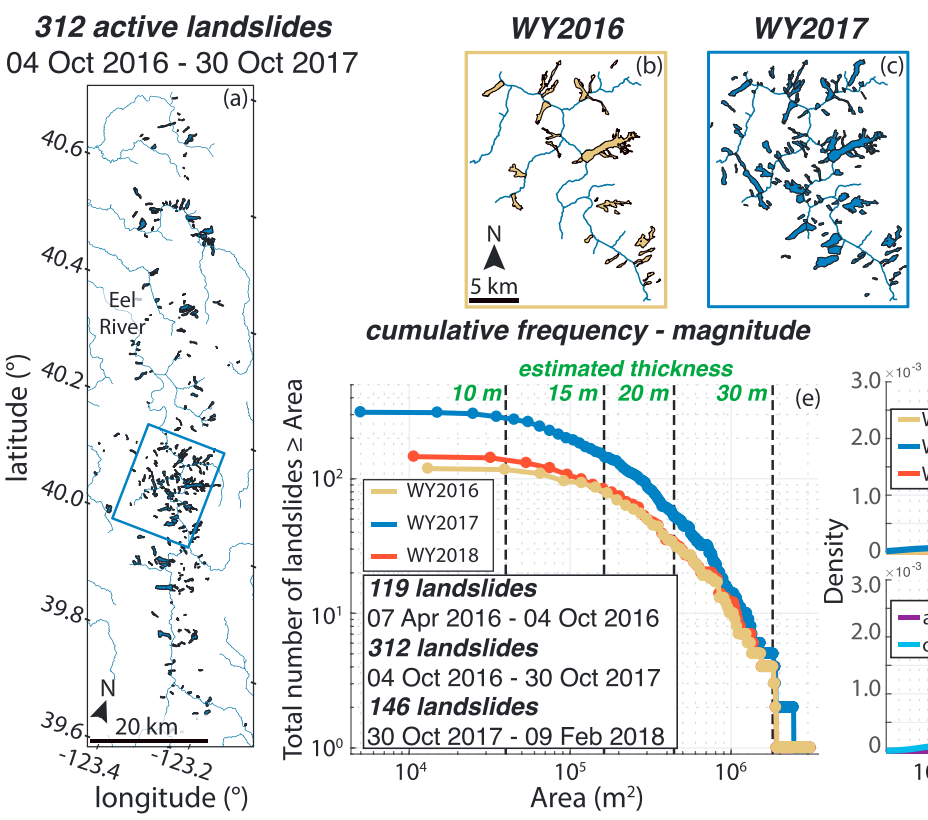

cumulative frequency - magnitude

estimated thickness
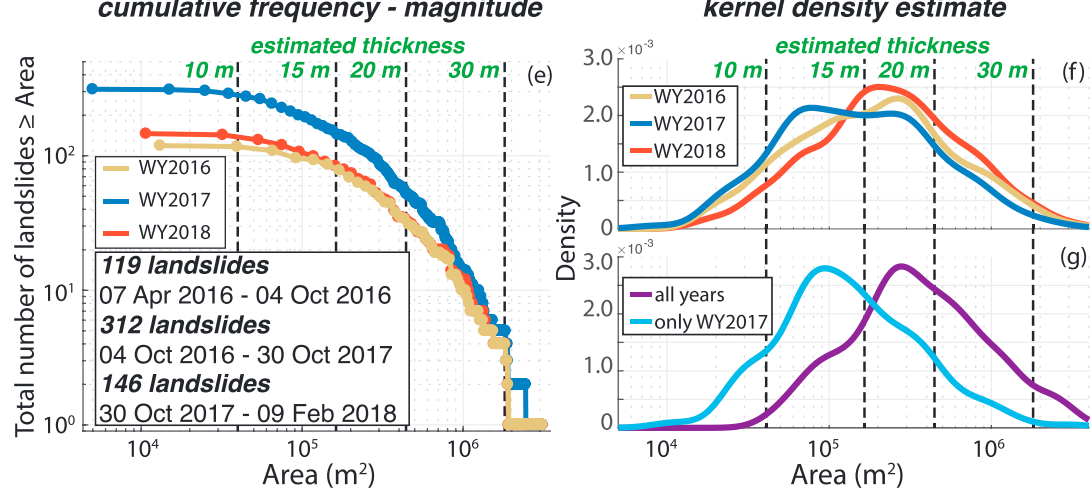

Figure 5. Landslide inventories by water year (WY). (a) Active landslides mapped during the WY2017. Thin blue lines correspond to major rivers and tributaries. (b-d) Active landslide map for WY2016, WY2017, and WY2018 for the boxed region shown in (a). (e) Cumulative number of active landslides and landslide area during each water year. Black dashed vertical lines show estimated landslide thickness. (f,g) Kernel density (i.e., probably density) estimate for the three water year landslide inventories, for landslides that are moving in all three time periods, and landslides only active in WY2017. Black dashed vertical lines show estimated landslide thickness. The increase in landslide activity is primarily accommodated by small- to medium-sized landslides area $<1 \times 10^{5} \mathrm{~m}^{2}$ and estimated thickness $<15 \mathrm{~m}$.

et al., 2013, 2015; Mackey \& Roering, 2011). To quantify the time-dependent changes in velocity, we selected a subset of 51 landslides for 3-D time series inversions using the pixel offset tracking method (Figure 6). These landslides were selected because they showed the strongest deformation signal when using the pixel offset tracking technique. We assume these landslides are representative of the Eel River landslides during our study period.

Figure 7 shows the characteristic horizontal displacement and velocity time series for the 51 landslides. We defined the characteristic values for each landslide as the 75th percentile value within the mapped landslide body (Bayer et al., 2018). This value gives less weight to the slower-moving areas and noisy areas with false high velocities that were not removed by our displacement thresholds (see example in Figure S3). We found that the maximum characteristic horizontal displacement for a single landslide over the full study period was $\sim 10 \mathrm{~m}$, the minimum displacement was $\sim 0.6 \mathrm{~m}$, and the median displacement for all 51 landslides was $\sim 2.7 \mathrm{~m}$. There was a large increase in displacement for each landslide that corresponded to the large increase in precipitation during WY2017. The landslide response to precipitation is even more evident when examining the normalized displacement and the normalized precipitation (Figure 8), which accentuates the deformation and precipitation patterns. The displacement patterns track the precipitation patterns with a time lag that is on the order of months. While we cannot more accurately resolve the time lag due to the infrequent sampling of the UAVSAR data (the median time period between data acquisitions was 75 days), this agrees with previous findings for the Eel River landslides (Handwerger et al., 2013). We also examined the velocity time series of each landslide (Figure 7). The maximum characteristic horizontal velocity for a single landslide was $\sim 16 \mathrm{~m}$ /year, which occurred during the wet season of WY2017, and the minimum characteristic horizontal velocities approached zero as a few of the landslides appeared to come to a complete halt during the dry season. There was also a large range in the landslide velocities during WY2017, when compared to WY2016 and WY2018. We compared the normalized velocity changes to the PDSI time series for our field area and found there is a good agreement (Figure 8). Velocities increase when the soil is becoming wetter and decrease when the soil is becoming dryer. The PDSI also indicates that during the WY2016 and WY2018, the region was under dry conditions, while almost all of WY2017 was under wet conditions (Figure 8). 


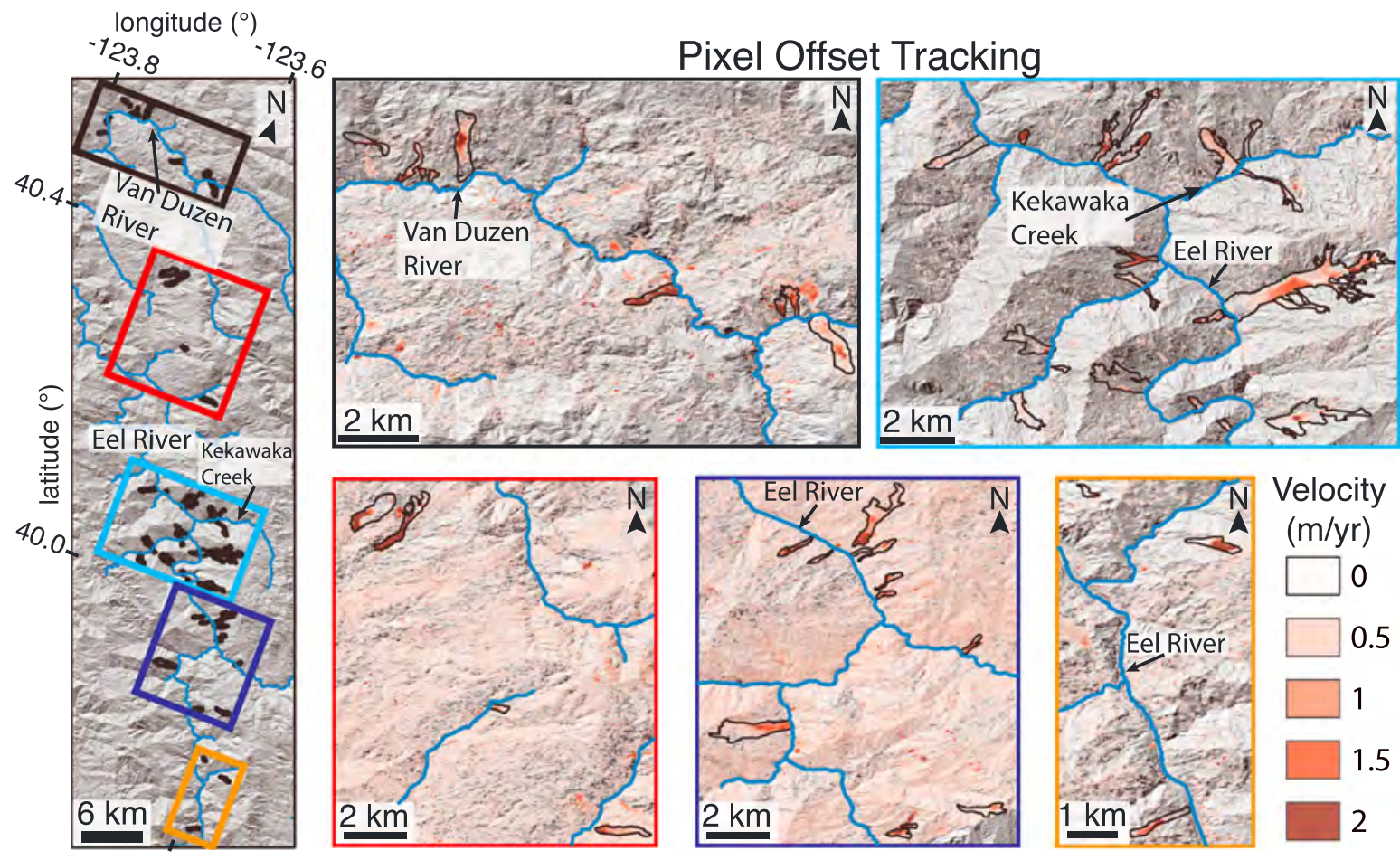

Figure 6. Velocity maps showing 51 landslides selected for pixel offset tracking time series. Color scale shows the horizontal velocity, which is draped over a hillshade of the topography. Black polygons show landslides used in the time series analysis (see Figures 7-9). Thin blue line shows river network. Insets show enlarged view of the landslides selected for analysis. We masked out areas with displacements $<0.2$ and $>20 \mathrm{~m}$. Digital elevation models from OpenTopography and TanDEM-X.

To better understand the relationship between precipitation, landslide velocity, and landslide geometry, we compared values over a similar time period for WY2016 and WY2017. For WY2016, we calculated the velocity between April 2016 and October 2016, and for WY2017, we calculated the velocity between March 2017 and October 2017. This time period spans the seasonal deceleration for both WYs. Figure 9 shows the ratio of the WY2017 velocity to WY2016 velocity as a function of estimated thickness and measured average width. We analyzed the landslide width in addition to the estimated thickness because the width has also been found to scale with thickness (e.g., Hovius et al., 1997). We find that 49 of the 51 landslides were moving faster during WY2017 when compared to a similar time period in WY2016 and that the smaller (i.e., narrower and thinner) landslides displayed larger velocity changes (Figure 9). There was up to a sixfold increase
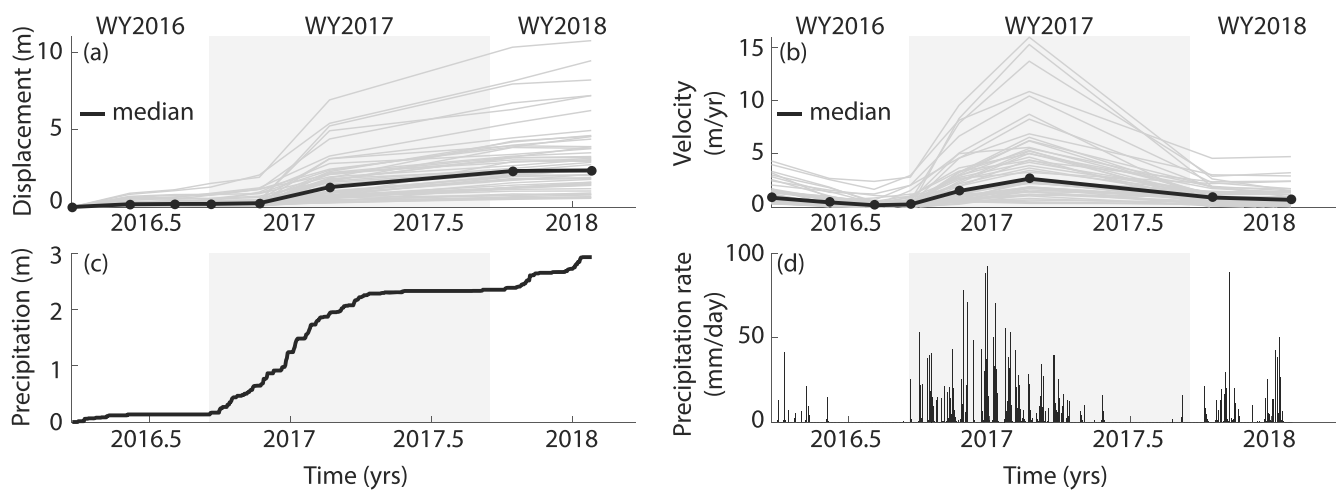

Figure 7. Displacement and velocity time series between April 2016 and February 2018. (a,b) Cumulative horizontal displacement and velocity time series. Gray lines correspond to characteristic value for the 51 landslides. Black line corresponds to median value for all 51 landslides. (c,d) Cumulative precipitation and precipitation rate time series. Shaded gray box highlights WY2017. Precipitation data from Parameter-elevation Regressions on Independent Slopes Model. WY = water year. 

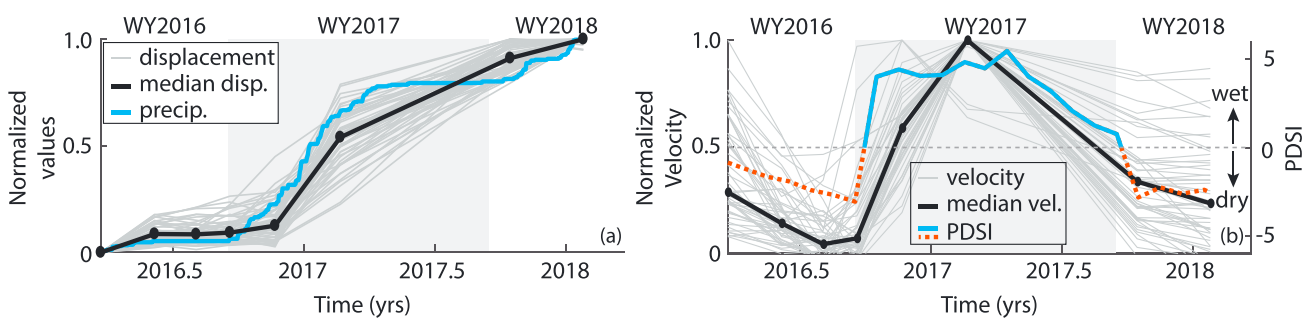

Figure 8. Normalized displacement and velocity time series. (a) Normalized cumulative horizontal displacement and cumulative precipitation time series. Gray lines correspond to characteristic value for each landslide. Black line corresponds to median displacement for the 51 landslides. Values are normalized to range between minimum $(\min =0)$ and maximum $(\max =1)$. (b) Normalized horizontal velocity time series and Palmer Drought Severity Index (PDSI). Gray lines correspond to characteristic value for each landslide. Black line corresponds to median velocity for the 51 landslides. Blue and dashed red line show PDSI and highlight wet and dry conditions, respectively. Shaded gray box highlights WY2017. Precipitation data from Parameter-elevation Regressions on Independent Slopes Model and PDSI data from the WestWide Drought Tracker. WY = water year.

in velocity for the smaller landslides and less than a twofold increase in velocity for the largest landslides. Interestingly, the two landslides that were moving slower during WY2017 were two of the smaller landslides whose velocities were $\sim 1.1$ times slower. We also found no relation between the landslide velocity ratio, mean velocity, and topographic slope (Figure 9). In addition to the size-dependent velocity response, we also explored how the spatial gradients in rainfall impacted the landslide velocity by examining the response from north to south and west to east (Figure S6). We found no clear relation between the spatial gradients in rainfall and the velocity ratio.
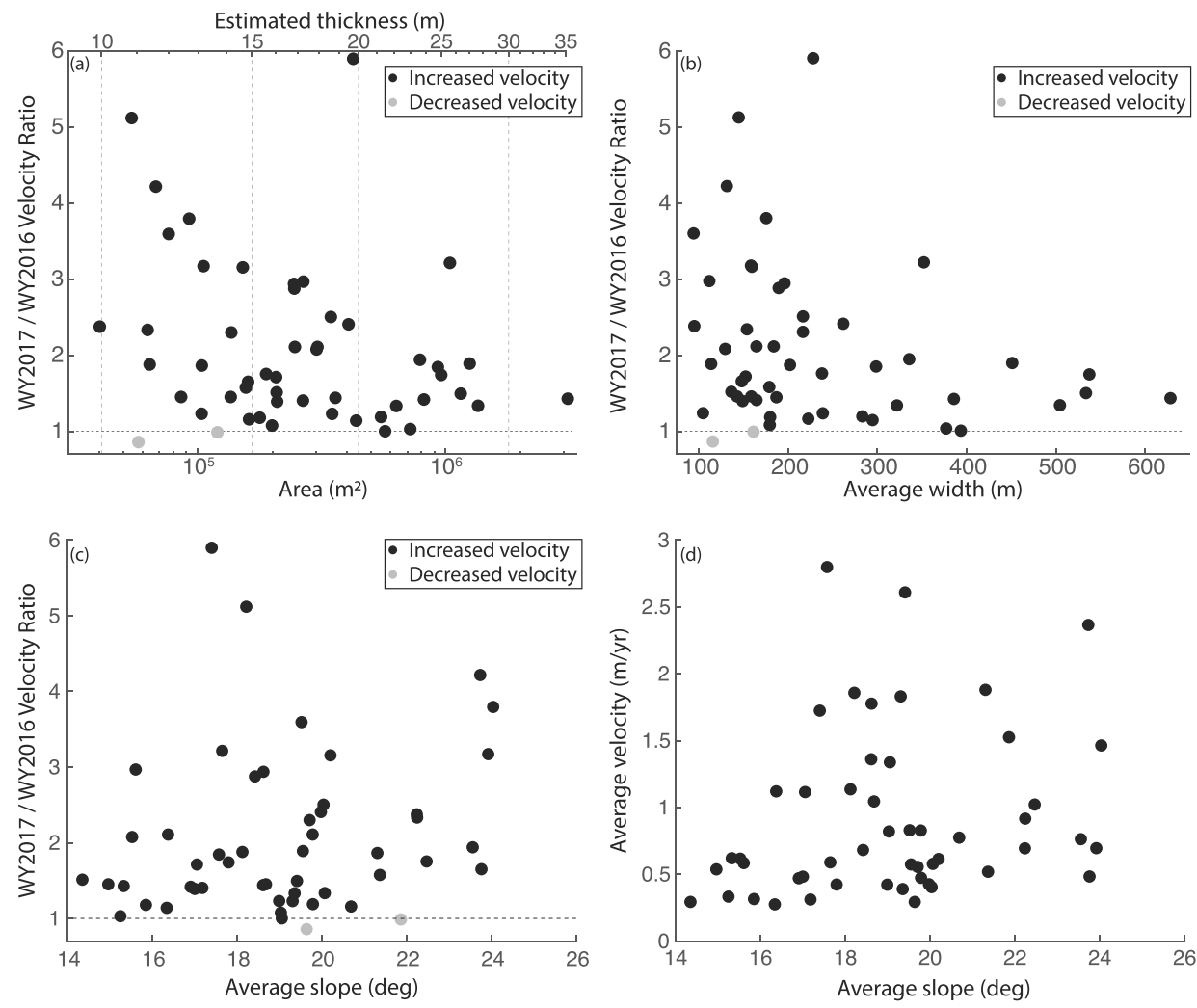

Figure 9. Landslide velocity as a function of size and topographic slope. (a) Velocity ratio as a function of landslide area and estimated thickness from area-thickness scaling relationships. Dashed vertical lines highlight constant thickness values. (b) Velocity ratio as a function of average landslide width. (c) Velocity ratio as a function of average slope angle. (d) Average velocity over the full study period as a function average slope angle. Velocity ratio is calculated over a similar time period for WY2017 (March-October 2017) and WY2016 (April-October 2016). Dashed horizontal lines in (a)-(c) show velocity ratio equal to one. WY = water year. 


\section{Discussion}

Our data reveal that large changes in the activity of slow-moving landslides occurred over a short time period in response to large changes in annual precipitation. We found that 312 landslides were moving due to the extreme rainfall of WY2017, compared to only 119 during the last drought year of WY2016. With a return to low rainfall amounts during WY2018, only 146 landslides remained in motion. We emphasize again that due to the irregular time sampling of the UAVSAR data, we likely underestimated the total number of active landslides in WY2016 and WY2018. Nonetheless, the role of antecedent rainfall is apparent in the temporal differences in landslide activity. We found that more landslides were moving in WY2018 than in WY2016, despite significantly lower rainfall in WY2018. This suggests that the above-average rainfall in WY2016 and WY2017 influenced the behavior of landslides in WY2018, while the period of below-average rainfall between WY2012 and WY2015 influenced the behavior of landslides in WY2016.

The majority of the landslides that were triggered or reactivated in WY2017 was smaller than the landslides that remained active between WY2016 and WY2018 (Figure 5). Using area-thickness scaling relations and measurements from DEMs, we found that landslides $<1 \times 10^{5} \mathrm{~m}^{2}$ and $<15 \mathrm{~m}$ thick were most sensitive to the precipitation changes (Figure 9). These observations suggest that larger and thicker landslides are less sensitive (but still responsive) to rainfall over monthly or annual timescales and also shows that there is still sufficient water (i.e., pore-water pressure) available to drive slow motion of many landslides even during dry conditions, while smaller and thinner landslides experience larger pore pressure swings that can both trigger motion and result in larger changes in velocity (Figures 9 and S7). These kinematic changes are consistent with changes in pore-water pressure recorded by ground-based measurements (Figure S7) and predicted by models, which show that stronger and more rapid pore-water pressure changes occur near the ground surface and diffuse as they propagate vertically downward (e.g., Berti \& Simoni, 2012; Iverson, 2000; Schulz, Smith, Wang, Jiang, Deuell, et al., 2018). Furthermore, our findings agree with Bennett, Roering, et al. (2016) who showed that landslides with estimated thicknesses $<15 \mathrm{~m}$ had the most variable velocities in the face of the recent historic drought.

By examining the time series behavior of 51 landslides, we found that each landslide displayed seasonal kinematic changes with a large increase in displacement and velocity during the extreme rainfall of WY2017 (Figure 7). Our findings agree with previous studies that have shown that landslides in the California Coast Ranges can display large displacements in certain years (Iverson \& Major, 1987; Mackey \& Roering, 2011; Nereson \& Finnegan, 2018). For example, Iverson and Major (1987) found that the Minor Creek landslide, northern California, displayed a large increase in displacement during WY1984 due to an unusually rainy summer in WY1983. In fact, WY1983 was the wettest year on record in California. Similarly, Nereson and Finnegan (2018) showed that the Oakridge landslide in central California, which also occurs in the Franciscan mélange, displayed large variations in annual displacement between 1937 and 2017 due to changes in climate-driven surface moisture.

Although these landslides displayed large increases in velocity, none of them (to our knowledge) continued to accelerate toward runaway instability and catastrophic failure, which suggests that these landslides might have a stabilizing mechanism that allows them to display slow sliding for long time periods. The two most common mechanisms invoked to explain this behavior are shear-induced dilatancy (e.g., Iverson, 2005; Schulz, McKenna, et al., 2009), which can cause a reduction in pore-water pressure, and shear-displacement and/or rate-strengthening friction (e.g., Handwerger et al., 2016; Keefer \& Johnson, 1983; Scaringi et al., 2018; Tika et al., 1996; Wang et al., 2010), both of which act to increase the frictional resistance during sliding. It is also possible that both of these mechanisms work in concert to inhibit runaway acceleration or that other strengthening mechanisms are important. For example, Schulz, Smith, Wang, Jiang, and Roering (2018) and Schulz, Smith, Wang, Jiang, Deuell, et al. (2018) performed advanced laboratory testing on material from the Two Towers landslide (located in our field area; see Figure 4) and found that shear resistance was invariant with shear-displacement rate (although tested rates were 2 orders of magnitude or more faster than observed landslides speed) and that there was no shear-induced dilatancy, which also was suggested by in situ monitoring results. However, they found that the soil swelling pressure exerted along the landslide's lateral shear zones increased landslide stability by as much as $6 \%$, which contributes to reducing the potential for catastrophic failure. In addition, we hypothesize that landslide drainage networks are important for reducing pore-water pressures and preventing runaway acceleration (e.g., Coe et al., 2003; Handwerger 
et al., 2013; Krzeminska et al., 2013; Van der Spek et al., 2013). These landslides tend to have well-developed surface and possibly subsurface, drainage networks that can efficiently transfer water to the river network and reduce pore-fluid pressures such that the landslide groundwater system typically maintains a narrow range of pore-water pressures that are sufficient to drive motion but is also susceptible to changes during years of extreme precipitation or drought. Given only our remote sensing data, we are unable to determine the relevant processes stabilizing the landslides that we studied. We highlight the need for further field and laboratory-based measurements and models, such as those utilized by Schulz, Smith, Wang, Jiang, and Roering (2018) and Schulz, Smith, Wang, Jiang, Deuell, et al. (2018), for multiple landslides in this region to better understand these processes.

Annual precipitation and precipitation extremes (i.e., dry-to-wet year transitions) are both predicted to increase in California over the next century (Allen \& Luptowitz, 2017; Swain et al., 2018; Zecca et al., 2018). The rainfall seasonality in California may also become more intense, with more rainfall delivered between December and March, with relatively less rainfall between September-November and March-May. Based on these predicted changes in precipitation and the findings of our study, we hypothesize there may be a preferential formation of smaller landslides, more frequent widespread landsliding, large changes in landslide displacement from year-to-year, and a more frequent transition of landslides between active and dormant. These changes in landslide activity could increase landslide hazards to humans and the built environment. Additionally, changes in the landslide activity over yearly timescales may alter the hillslope morphology, drainage networks, and the timing and volume of sediment delivered to rivers, which could in turn modify channel incision and hillslope evolution (e.g., Bennett, Miller, et al., 2016; Booth et al., 2013; Golly et al., 2017; Kelsey, 1978; Korup et al., 2010; Mackey \& Roering, 2011; Nereson \& Finnegan, 2018; Ouimet et al., 2007; Sklar \& Dietrich, 2004; Whipple, 2004). More work is needed to better understand the interactions between hillslopes and channels in areas dominated by slow-moving landslides during dry-to-wet year transitions.

Our findings document the sensitivity of slow-moving landslides to large changes in annual precipitation. These findings agree with numerous studies of both slow- and fast-moving landslides around the world that have highlighted potential impacts of climate change on landslide behaviors (e.g., Crozier, 2010; Gariano \& Guzzetti, 2016). Although it is likely that increases in landslide activity will occur in regions where precipitation is likely to increase due to climate change (e.g., Bovis \& Jones, 1992; Jakob \& Lambert, 2009; Chiang \& Chang, 2011), there are also regions where precipitation, and therefore landslide activity, is predicted to decrease (e.g., Coe, 2012; Gariano \& Guzzetti, 2016). Furthermore, regional changes in climate patterns may influence the style and type of landslides, such that changes in individual storms will likely influence shallow landslide activity, while changes in seasonal and annual precipitation will likely influence deep-seated landslide activity. It is therefore imperative that we improve mechanical-hydrological models that can predict the future behavior of landslides given inputs from climate models (e.g., Chiang \& Chang, 2011; Coe, 2012; Gariano \& Guzzetti, 2016; Nereson \& Finnegan, 2018). Thus, documenting the past and present landslide response to changes in precipitation that may mimic future climate scenarios in different regions around the world is essential to provide insight into future landslide behaviors, hazards, and landscape evolution.

\section{Conclusions}

We used a novel data set acquired by the NASA/JPL UAVSAR airborne SAR interferometry system to identify and monitor hundreds of slow-moving landslides in the Eel River catchment, northern California, between April 2016 and February 2018. During this time period, there were large changes in annual precipitation, including the 2017 rainy season, which was the second wettest year on record in California and which followed a multiyear period of extreme drought. We quantified changes in landslide activity and kinematics over the $\sim 2$-year study period and determined that the extreme rainfall of 2017 triggered a widespread but short-lived increase in the activity and velocity of the landslides. These kinematic changes were the strongest in the smallest landslides and highlight the sensitivity of these landslides to large changes in precipitation. Based on future predictions of climate change and precipitation occurring over the next century, we expect that there will be large changes in landslide behavior that may increase landslide hazards to humans and cause sediment delivery to streams to be more extreme and episodic. We therefore highlight the need for observations and models that can help predict such precipitation-induced changes to landslide activity. 
Acknowledgments

We thank Ben Mackey for sharing mapped landslide polygons. We thank Joshua Roering for discussions on the Eel River landslides. We thank Chris Milliner and Odin Marc for discussion on frequency-magnitude relationships. We thank Yang Zheng and the UAVSAR flight and data processing teams for their help with acquiring and processing the data. We thank Jon Perkins, Harvey Kelsey, Jeff Coe, Amy East, and one anonymous reviewer for constructive reviews. Part of this research was sponsored by the NASA Earth Surface and Interior focus area and performed at the Jet Propulsion Laboratory, California Institute of Technology. A. L. H.'s research was supported by an appointment to the NASA Postdoctoral Program at the Jet Propulsion Laboratory, administered by Universities Space Research Association under contract with NASA. The precipitation data are provided by the PRISM Climate Group and may be downloaded online (http://prism.oregonstate.edu). The PDSI data are provided by the WestWide Drought Tracker and may be downloaded through their website (https://wrcc.dri.edu/wwdt/). Lidar digital elevation models are provided by OpenTopography and may be downloaded online (http://www. opentopography.org).

OpenTopography lidar data acquisition and processing was completed by the National Center for Airborne Laser Mapping (NCALM; http://www.ncalm. org). NCALM funding was provided by NSF's Division of Earth Sciences, Instrumentation and Facilities Program EAR-1043051. Topographic data are also provided by the German Aerospace Center (DLR) under data proposal DEM GEOL1478 awarded to A. L. H. To acquire these data, proposals may be submitted to the DLR online (https://tandemx-science.dlr. de/). NASA/JPL UAVSAR data used in this study may be downloaded through their website (https://uavsar.jpl.nasa. gov/). The California geologic map is provided by the U.S. Geological Survey (https://mrdata.usgs.gov/geology/ state). Any use of trade, product, or firm names is for descriptive purposes only and does not imply endorsement by the U.S. Government.

\section{References}

Agram, P., Jolivet, R., Riel, B., Lin, Y., Simons, M., Hetland, E., et al. (2013). New radar interferometric time series analysis toolbox released. EOS, Transactions American Geophysical Union, 94(7), 69-70.

Allen, R. J., \& Luptowitz, R. (2017). El Niño-like teleconnection increases California precipitation in response to warming. Nature communications, 8,16055 .

Bao, H., Ampuero, J.-P., Meng, L., Fielding, E. J., Liang, C., Milliner, C. W. D., et al. (2019). Early and persistent supershear rupture of the 2018 magnitude 7.5 Palu earthquake. Nature Geoscience, 12, 200-205.

Bayer, B., Simoni, A., Mulas, M., Corsini, A., \& Schmidt, D. (2018). Deformation responses of slow moving landslides to seasonal rainfall in the Northern Apennines, measured by InSAR. Geomorphology, 308, 293-306.

Bekaert, D. P., Jones, C. E., An, K., \& Huang, M.-H. (2019). Exploiting UAVSAR for a comprehensive analysis of subsidence in the Sacramento Delta. Remote sensing of environment, 220, 124-134.

Bell, A. F. (2018). Predictability of landslide timing from quasi-periodic precursory earthquakes. Geophysical Research Letters, 45, 1860-1869. https://doi.org/10.1002/2017GL076730

Bennett, G. L., Miller, S. R., Roering, J. J., \& Schmidt, D. A. (2016). Landslides, threshold slopes, and the survival of relict terrain in the wake of the Mendocino Triple Junction. Geology, 44(5), 363-366.

Bennett, G. L., Roering, J. J., Mackey, B. H., Handwerger, A. L., Schmidt, D. A., \& Guillod, B. P. (2016). Historic drought puts the brakes on earthflows in Northern California. Geophysical Research Letters, 43, 5725-5731. https://doi.org/10.1002/2016GL068378

Berardino, P., Fornaro, G., Lanari, R., \& Sansosti, E. (2002). A new algorithm for surface deformation monitoring based on small baseline differential SAR interferograms. IEEE Transactions on Geoscience and Remote Sensing, 40(11), 2375-2383.

Berti, M., \& Simoni, A. (2012). Observation and analysis of near-surface pore-pressure measurements in clay-shales slopes. Hydrological Processes, 26(14), 2187-2205.

Booth, A. M., McCarley, J., Hinkle, J., Shaw, S., Ampuero, J.-P., \& Lamb, M. P. (2018). Transient reactivation of a deep-seated landslide by undrained loading captured with repeat airborne and terrestrial lidar. Geophysical Research Letters, 45, 4841-4850. https://doi.org/10. 1029/2018GL077812

Booth, A. M., \& Roering, J. J. (2011). A 1-D mechanistic model for the evolution of earthflow-prone hillslopes. Journal of Geophysical Research, 116, F04021. https://doi.org/10.1029/2011JF002024

Booth, A. M., Roering, J. J., \& Rempel, A. W. (2013). Topographic signatures and a general transport law for deep-seated landslides in a landscape evolution model. Journal of Geophysical Research: Earth Surface, 118, 603-624. https://doi.org/10.1002/jgrf.20051

Bovis, M. J., \& Jones, P. (1992). Holocene history of earthflow mass movements in south-central British Columbia: The influence of hydroclimatic changes. Canadian Journal of Earth Sciences, 29(8), 1746-1755.

Cerovski-Darriau, C., \& Roering, J. J. (2016). Influence of anthropogenic land-use change on hillslope erosion in the Waipaoa River Basin, New Zealand. Earth Surface Processes and Landforms, 41(15), 2167-2176.

Chaussard, E., Milillo, P., Bürgmann, R., Perissin, D., Fielding, E. J., \& Baker, B. (2017). Remote sensing of ground deformation for monitoring groundwater management practices: Application to the Santa Clara Valley during the 2012-2015 California drought. Journal of Geophysical Research: Solid Earth, 122, 8566-8582. https://doi.org/10.1002/2017JB014676

Chiang, S.-H., \& Chang, K.-T. (2011). The potential impact of climate change on typhoon-triggered landslides in Taiwan, 2010-2099. Geomorphology, 133(3-4), 143-151.

Coe, J. A. (2012). Regional moisture balance control of landslide motion: Implications for landslide forecasting in a changing climate. Geology, 40(4), 323-326.

Coe, J. A., Ellis, W. L., Godt, J. W., Savage, W. Z., Savage, J. E., Michael, J., et al. (2003). Seasonal movement of the Slumgullion landslide determined from Global Positioning System surveys and field instrumentation, July 1998-March 2002. Engineering Geology, 68(1), 67-101.

Cohen-Waeber, J., Bürgmann, R, Chaussard, E., Giannico, C., \& Ferretti, A. (2018). Spatiotemporal patterns of precipitation-modulated landslide deformation from independent component analysis of InSAR time series. Geophysical Research Letters, 45, 1878-1887. https:// doi.org/10.1002/2017GL075950

Colesanti, C., \& Wasowski, J. (2006). Investigating landslides with space-borne Synthetic Aperture Radar (SAR) interferometry. Engineering geology, 88(3), 173-199.

Crozier, M. J. (2010). Deciphering the effect of climate change on landslide activity: A review. Geomorphology, 124(3-4), 260-267.

Dehecq, A., Gourmelen, N., \& Trouvé, E. (2015). Deriving large-scale glacier velocities from a complete satellite archive: Application to the Pamir-Karakoram-Himalaya. Remote Sensing of Environment, 162, 55-66.

Delbridge, B. G., Bürgmann, R., Fielding, E., Hensley, S., \& Schulz, W. H. (2016). Three-dimensional surface deformation derived from airborne interferometric UAVSAR: Application to the Slumgullion Landslide. Journal of Geophysical Research: Solid Earth, 121, 3951-3977. https://doi.org/10.1002/2015JB012559

Dettinger, M. D., Ralph, F. M., Das, T., Neiman, P. J., \& Cayan, D. R. (2011). Atmospheric rivers, floods and the water resources of California Water, 3(2), 445-478.

Diffenbaugh, N. S., Swain, D. L., \& Touma, D. (2015). Anthropogenic warming has increased drought risk in California. Proceedings of the National Academy of Sciences, 112, 3931-3936.

East, A. E., Stevens, A. W., Ritchie, A. C., Barnard, P. L., Campbell-Swarzenski, P., Collins, B. D., \& Conaway, C. H. (2018). A regime shift in sediment export from a coastal watershed during a record wet winter, California: Implications for landscape response to hydroclimatic extremes. Earth Surface Processes and Landforms, 43(12), 2562-2577.

Fialko, Y., Simons, M., \& Agnew, D. (2001). The complete (3-D) surface displacement field in the epicentral area of the $1999 M_{W} 7.1 \mathrm{Hector}$ Mine Earthquake, California, from space geodetic observations. Geophysical Research Letters, 28(16), 3063-3066.

Fielding, E. J., Talebian, M., Rosen, P. A., Nazari, H., Jackson, J. A., Ghorashi, M., \& Walker, R. (2005). Surface ruptures and building damage of the 2003 Bam, Iran, earthquake mapped by satellite synthetic aperture radar interferometric correlation. Journal of Geophysical Research, 110, B03302. https://doi.org/10.1029/2004JB003299

Froude, M. J., \& Petley, D. (2018). Global fatal landslide occurrence from 2004 to 2016. Natural Hazards and Earth System Sciences, 18, 2161-2181.

Gariano, S. L., \& Guzzetti, F. (2016). Landslides in a changing climate. Earth-Science Reviews, 162, 227-252.

Gershunov, A., Shulgina, T., Ralph, FMartin, Lavers, D. A., \& Rutz, J. J. (2017). Assessing the climate-scale variability of atmospheric rivers affecting western North America. Geophysical Research Letters, 44, 7900-7908. https://doi.org/10.1002/2017GL074175

Goldstein, R. M., \& Werner, C. L. (1998). Radar interferogram filtering for geophysical applications. Geophysical research letters, 25(21), $4035-4038$ 
Golly, A., Turowski, J. M., Badoux, A., \& Hovius, N. (2017). Controls and feedbacks in the coupling of mountain channels and hillslopes. Geology, 45(4), 307-310.

Gourmelen, N., Kim, S., Shepherd, A., Park, J., Sundal, A., Björnsson, H, \& Pálsson, F (2011). Ice velocity determined using conventional and multiple-aperture insar. Earth and Planetary Science Letters, 307(1-2), 156-160.

Griffin, D., \& Anchukaitis, K. J. (2014). How unusual is the 2012-2014 California drought? Geophysical Research Letters, 41, 9017-9023. https://doi.org/10.1002/2014GL062433

Guirguis, K., Gershunov, A., Clemesha, R. E., Shulgina, T., Subramanian, A. C., \& Ralph, FMartin (2018). Circulation drivers of atmospheric rivers at the North American West Coast. Geophysical Research Letters, 45, 12,576-12,584. https://doi.org/10.1029/2018GL079249

Guzzetti, F., Ardizzone, F., Cardinali, M., Rossi, M., \& Valigi, D. (2009). Landslide volumes and landslide mobilization rates in Umbria, Central Italy. Earth and Planetary Science Letters, 279(3-4), 222-229.

Handwerger, A. L., Huang, M.-H., Fielding, E. J., Booth, A. M., \& Bürgmann, R. (2019). A shift from drought to extreme rainfall drives a stable landslide to catastrophic failure. Scientific Reports, 9(1), 1569.

Handwerger, A. L., Rempel, A. W., Skarbek, R. M., Roering, J. J., \& Hilley, G. E. (2016). Rate-weakening friction characterizes both slow sliding and catastrophic failure of landslides. Proceedings of the National Academy of Sciences, 113(37), 10,281-10,286.

Handwerger, A. L., Roering, J. J., \& Schmidt, D. A. (2013). Controls on the seasonal deformation of slow-moving landslides. Earth and Planetary Science Letters, 377, 239-247.

Handwerger, A. L., Roering, J. J., Schmidt, D. A., \& Rempel, A. W. (2015). Kinematics of earthflows in the Northern California Coast Ranges using satellite interferometry. Geomorphology, 246, 321-333.

Hilley, G. E., Bürgmann, R., Ferretti, A., Novali, F., \& Rocca, F. (2004). Dynamics of slow-moving landslides from permanent scatterer analysis. Science, 304(5679), 1952-1955.

Hovius, N., Stark, C. P., \& Allen, P. A. (1997). Sediment flux from a mountain belt derived by landslide mapping. Geology, 25(3), 231-234.

Hu, X., Wang, T., Pierson, T. C., Lu, Z., Kim, J., \& Cecere, T. H. (2016). Detecting seasonal landslide movement within the cascade landslide complex (Washington) using time-series SAR imagery. Remote Sensing of Environment, 187, 49-61.

Huang, M.-H., Fielding, E. J., Dickinson, H., Sun, J., Gonzalez-Ortega, J. A., Freed, A. M., \& Bürgmann, R. (2017). Fault geometry inversion and slip distribution of the $2010 \mathrm{Mw}$ 7.2 El Mayor-Cucapah earthquake from geodetic data. Journal of Geophysical Research: Solid Earth, 122, 607-621. https://doi.org/10.1002/2016JB012858

Huang, M.-H., Fielding, E. J., Liang, C., Milillo, P., Bekaert, D., Dreger, D., \& Salzer, J. (2017). Coseismic deformation and triggered landslides of the $2016 \mathrm{Mw} 6.2$ Amatrice earthquake in Italy. Geophysical Research Letters, 44, 1266-1274. https://doi.org/10.1002/ 2016GL071687

Hutchinson, J., \& Bhandari, R. (1971). Undrained loading, a fundamental mechanism of mudflows and other mass movements. Geotechnique, 21(4), 353-358.

Iverson, R. M. (2000). Landslide triggering by rain infiltration. Water resources research, 36(7), 1897-1910.

Iverson, R. M. (2005). Regulation of landslide motion by dilatancy and pore pressure feedback. Journal of Geophysical Research, 110 , F02015. https://doi.org/10.1029/2004JF000268

Iverson, R. M., George, D. L., Allstadt, K., Reid, M. E., Collins, B. D., Vallance, J. W., et al. (2015). Landslide mobility and hazards: Implications of the 2014 Oso disaster. Earth and Planetary Science Letters, 412, 197-208.

Iverson, R. M., \& Major, J. J. (1987). Rainfall, ground-water flow, and seasonal movement at Minor Creek landslide, northwestern California: Physical interpretation of empirical relations. Geological Society of America Bulletin, 99(4), 579-594.

Jakob, M., \& Lambert, S. (2009). Climate change effects on landslides along the southwest coast of British Columbia. Geomorphology, 107(3-4), 275-284.

Jayko, A., Blake, M., McLaughlin, R., Ohlin, H., Ellen, S., \& Kelsey, H. (1989). Reconnaissance geologic map of the covelo 30- by 60-minute quadrangle, vol. 1. Northern California: US Geological Survey Miscellaneous Field Investigation Map MF-2001, scale.

Jennings, C. W., Strand, R. G., \& Rogers, T. H. (1977). Geologic map of California: California Division of Mines and Geology, scale 1:750,000.

Keefer, D. K., \& Johnson, A. M. (1983). Earth flows: Morphology, mobilization, and movement. Washington: United States Government Printig Office.

Kelsey, H. M. (1978). Earthflows in Franciscan melange, Van Duzen River Basin, California. Geology, 6(6), 361-364.

Kirschbaum, D., Stanley, T., \& Zhou, Y. (2015). Spatial and temporal analysis of a global landslide catalog. Geomorphology, $249,4-15$.

Korup, O., Clague, J. J., Hermanns, R. L., Hewitt, K., Strom, A. L., \& Weidinger, J. T. (2007). Giant landslides, topography, and erosion. Earth and Planetary Science Letters, 261(3-4), 578-589.

Korup, O., Densmore, A. L., \& Schlunegger, F. (2010). The role of landslides in mountain range evolution. Geomorphology, 120(1-2), 77-90.

Krzeminska, D., Bogaard, T., Malet, J.-P., \& Van Beek, L. (2013). A model of hydrological and mechanical feedbacks of preferential fissure flow in a slow-moving landslide. Hydrology and Earth System Sciences, 17(3), 947-959.

Lacroix, P, Berthier, E., \& Maquerhua, E. T. (2015). Earthquake-driven acceleration of slow-moving landslides in the Colca Valley, Peru, detected from Pléiades images. Remote Sensing of Environment, 165, 148-158.

Larsen, I. J., Montgomery, D. R., \& Korup, O. (2010). Landslide erosion controlled by hillslope material. Nature Geoscience, $3(4), 247$.

Leprince, S., Berthier, E., Ayoub, F., Delacourt, C., \& Avouac, J.-P. (2008). Monitoring earth surface dynamics with optical imagery. EOS, Transactions American Geophysical Union, 89(1), 1-2.

Mackey, B. H., \& Roering, J. J. (2011). Sediment yield, spatial characteristics, and the long-term evolution of active earthflows determined from airborne lidar and historical aerial photographs, Eel River, california. Bulletin, 123(7-8), 1560-1576.

Mackey, B. H., Roering, J. J., \& Lamb, M. P. (2011). Landslide-dammed paleolake perturbs marine sedimentation and drives genetic change in anadromous fish. Proceedings of the National Academy of Sciences, 108(47), 18905-18909.

Mackey, B., Roering, J., \& McKean, J. (2009). Long-term kinematics and sediment flux of an active earthflow, Eel River, California. Geology, 37(9), 803-806.

Malet, J.-P., Maquaire, O., \& Calais, E. (2002). The use of global positioning system techniques for the continuous monitoring of landslides: Application to the super-sauze earthflow (Alpes-de-Haute-Provence, France). Geomorphology, 43(1-2), 33-54.

McLaughlin, R. J., Blake, S., Jayko, M., Irwin, A., Aalto, W., Carver, K., et al. (2000). Geologic map of the Cape Mendocino, Eureka, Garberville, and southwestern part of the Hayfork 30 X 60 Quadrangles and Adjacent Offshore Area, Northern California.

McLaughlin, R. J., Kling, S. A., Poore, R. Z., McDougall, K., \& Beutner, E. C. (1982). Post-middle Miocene accretion of Franciscan rocks, northwestern California. Geological Society of America Bulletin, 93(7), 595-605.

Miao, H., Wang, G., Yin, K., Kamai, T., \& Li, Y. (2014). Mechanism of the slow-moving landslides in Jurassic red-strata in the Three Gorges Reservoir, China. Engineering geology, 171, 59-69.

Milillo, P., Rignot, E., Rizzoli, P., Scheuchl, B., Mouginot, J., Bueso-Bello, J., \& Prats-Iraola, P. (2019). Heterogeneous retreat and ice melt of Thwaites Glacier, West Antarctica. Science Advances, 5(1), eaau3433. 
Murray, K. D., \& Lohman, R. B. (2018). Short-lived pause in Central California subsidence after heavy winter precipitation of 2017. Science Advances, 4(8), eaar8144.

Nereson, A., Davila Olivera, S., \& Finnegan, N. (2018). Field and remote-sensing evidence for hydro-mechanical isolation of a long-lived earthflow in central california. Geophysical Research Letters, 45, 9672-9680. https://doi.org/10.1029/2018GL079430

Nereson, A. L., \& Finnegan, N. J. (2018). Drivers of earthflow motion revealed by an $80 \mathrm{yr}$ record of displacement from Oak Ridge earthflow, Diablo Range, California, USA. Geological Society of America Bulletin, 131, 389-402.

Ouimet, W. B., Whipple, K. X., Royden, L. H., Sun, Z., \& Chen, Z. (2007). The influence of large landslides on river incision in a transient landscape: Eastern margin of the Tibetan Plateau (Sichuan, China). Geological Society of America Bulletin, 119(11-12), 1462-1476.

Pathier, E., Fielding, E., Wright, T., Walker, R., Parsons, B., \& Hensley, S. (2006). Displacement field and slip distribution of the 2005 Kashmir earthquake from SAR imagery. Geophysical Research Letters, 33, L20310. https://doi.org/10.1029/2006GL027193

Robeson, S. M. (2015). Revisiting the recent california drought as an extreme value. Geophysical Research Letters, 42, 6771-6779. https:// doi.org/10.1002/2015GL064593

Roering, J. J., Mackey, B. H., Handwerger, A. L., Booth, A. M., Schmidt, D. A., Bennett, G. L., \& Cerovski-Darriau, C. (2015). Beyond the angle of repose: A review and synthesis of landslide processes in response to rapid uplift, Eel River, Northern California. Geomorphology, 236, 109-131.

Roering, J. J., Stimely, L. L., Mackey, B. H., \& Schmidt, D. A. (2009). Using DInSAR, airborne LiDAR, and archival air photos to quantify landsliding and sediment transport. Geophysical Research Letters, 36, L19402. https://doi.org/10.1029/2009GL040374

Rosen, P. A., Gurrola, E., Sacco, G. F., \& Zebker, H. (2012). The InSAR scientific computing environment (730-733). Nuremberg, Germany: Proc. EUSAR.

Rutter, E., \& Green, S. (2011). Quantifying creep behaviour of clay-bearing rocks below the critical stress state for rapid failure: Mam Tor landslide, Derbyshire, England. Journal of the Geological Society, 168(2), 359-372.

Scaringi, G., Hu, W., Xu, Q., \& Huang, R. (2018). Shear-rate-dependent behavior of clayey bimaterial interfaces at landslide stress levels. Geophysical Research Letters, 45, 766-777. https://doi.org/10.1002/2017GL076214

Scheingross, J. S., Minchew, B. M., Mackey, B. H., Simons, M., Lamb, M. P., \& Hensley, S. (2013). Fault-zone controls on the spatial distribution of slow-moving landslides. Geological Society of America Bulletin, 125(3-4), 473-489.

Schlögel, R., Doubre, C., Malet, J.-P., \& Masson, F. (2015). Landslide deformation monitoring with ALOS/PALSAR imagery: A D-InSAR geomorphological interpretation method. Geomorphology, 231, 314-330.

Schmidt, D. A., \& Bürgmann, R. (2003). Time-dependent land uplift and subsidence in the Santa Clara Valley, California, from a large interferometric synthetic aperture radar data set. Journal of Geophysical Research, 108(B9), 2416. https://doi.org/10.1029/2002JB002267

Schulz, W. H., Kean, J. W., \& Wang, G. (2009). Landslide movement in southwest Colorado triggered by atmospheric tides. Nature Geoscience, 2(12), 863-866.

Schulz, W. H., McKenna, J. P., Kibler, J. D., \& Biavati, G. (2009). Relations between hydrology and velocity of a continuously moving landslide-evidence of pore-pressure feedback regulating landslide motion? Landslides, 6(3), 181-190.

Schulz, W. H., Smith, J. B., Wang, G., Jiang, Y., Deuell, A., Reeves, R., et al. (2018). Data from in-situ landslide monitoring. Trinity County, California: U. S. Geological Survey data release.

Schulz, W. H., Smith, J. B., Wang, G., Jiang, Y., \& Roering, J. J. (2018). Clayey landslide initiation and acceleration strongly modulated by soil swelling. Geophysical Research Letters, 45, 1888-1896. https://doi.org/10.1002/2017GL076807

Simoni, A., Ponza, A., Picotti, V., Berti, M., \& Dinelli, E. (2013). Earthflow sediment production and holocene sediment record in a large apennine catchment. Geomorphology, 188, 42-53.

Sklar, L. S., \& Dietrich, W. E. (2004). A mechanistic model for river incision into bedrock by saltating bed load. Water Resources Research, 40, W06301. https://doi.org/10.1029/2003WR002496

Stumpf, A., Malet, J.-P., \& Delacourt, C. (2017). Correlation of satellite image time-series for the detection and monitoring of slow-moving landslides. Remote Sensing of Environment, 189, 40-55.

Swain, D. L., Horton, D. E., Singh, D., \& Diffenbaugh, N. S. (2016). Trends in atmospheric patterns conducive to seasonal precipitation and temperature extremes in California. Science Advances, 2(4), e1501344.

Swain, D. L., Langenbrunner, B., Neelin, J. D., \& Hall, A. (2018). Increasing precipitation volatility in twenty-first-century california. Nature Climate Change, 8(5), 427.

Terzaghi, K. (1950). Mechanism of landslides. In S. Paige (Ed.), Application of geology to engineering practice (Berkey volume). New York: Geological Society of America.

Tika, T. E., Vaughan, P. R., \& Lemos, L. J. L. J. (1996). Fast shearing of pre-existing shear zones in soil. Geotechnique, 46(2), 197-233.

Van Genuchten, P., \& De Rijke, H. (1989). On pore water pressure variations causing slide velocities and accelerations observed in a seasonally active landslide. Earth Surface Processes and Landforms, 14(6), 577-586.

Van der Spek, J., Bogaard, T., \& Bakker, M. (2013). Characterization of groundwater dynamics in landslides in varved clays. Hydrology and Earth System Sciences, 17(6), 2171-2183.

Wang, G., Suemine, A., \& Schulz, W. H. (2010). Shear-rate-dependent strength control on the dynamics of rainfall-triggered landslides, Tokushima Prefecture, Japan. Earth Surface Processes and Landforms, 35(4), 407-416.

Warrick, J. A., Ritchie, A. C., Schmidt, K. M., Reid, M. E., \& Logan, J. (2019). Characterizing the catastrophic 2017 Mud Creek landslide, California, using repeat structure-from-motion (SfM) photogrammetry. Landslides, 16, 1201-1219.

Whipple, K. X. (2004). Bedrock rivers and the geomorphology of active orogens. Annual Review of Earth and Planetary Sciences, 32, 151-185.

Zecca, K., Allen, R. J., \& Anderson, R. G. (2018). Importance of the El Nino teleconnection to the 21st century California wintertime extreme precipitation increase. Geophysical Research Letters, 45, 10,648-10,655. https://doi.org/10.1029/2018GL079714

Zhao, C., Lu, Z., Zhang, Q., \& de La Fuente, J. (2012). Large-area landslide detection and monitoring with ALOS/PALSAR imagery data over northern California and southern Oregon, USA. Remote Sensing of Environment, 124, 348-359. 